\title{
Confessions of a Flaneur
}

JOHN THOMAS GIORDANO

ASSUMPTION UNIVERSITY

BANGKOK, THAILAND

\section{SEAMS AND FLOWS IN METRO MANILA}

\section{Journey}

$\mathrm{I}^{\mathrm{t}}$ has rained. The water has run down the roofs, through the streets, and gradually disappeared into the storm-drains.

It's Friday night again and, on cue, I'm on my way to browse around at a bookstore imbedded in a Makati shopping mall.

I walk down to Aurora Boulevard to catch a jeepney that takes me to Cubao. I get off under a whole bunch of hand-painted movie posters perched high above the street, and weave my way through the crowds in the direction of the Cubao Light Rail Station, past tables of pirated pornographic videos for sale. There, however, is no time to look; my desires being more archival, I need to get to the bookstore before it closes.

I get off the train at the Guadalupe Station, from where I walk the back streets of the community. Guadalupe is not a shantytown, but an old neighborhood on a slope going all the way down to the Pasig River, built back when the Pasig was an important waterway. I stroll through the neighborhood fancying myself as somewhat of a flaneur. But I am never completely invisible. Now and then someone calls out, "Hey Joe!," whereupon the world intrudes upon my reflections and I fold back upon myself.

The same thing happens when I take a shortcut to the market through the shantytowns. Not only do people call out to me, they often stop me, suspicious of why I'm there. When they see that they have startled me, they are always forthcoming with assurances that I need 
fear nothing. An older man, a community leader in "Marytown," once described to me the pride everyone in his community takes in it. They are not merely "the poor," but individuals who are cashiers, security guards, secretaries, and other types of professionals.

I am on my way of course to find a book. I have an important talk coming up. Something about cities. And I remember seeing an interesting architectural book on city density. It had a little essay about something called re-embedding. Books are a little expensive at this store so I put paper and a pencil in my breast pocket, prepared to make off with whatever information I might come across.

Here, in a true Rabelaisian spirit, I provide a listing of books I have either bought or sought out, and some of those other (pirated) items I picked up on previous journeys to the bookstore.

Books

FARMAX

Hardt and Negri's Empire

Inner Navigation

Benjamin's Arcades Project

Benjamin's Selected Writings vol. 3

$\mathrm{X}$ rated VCDs

Hustler's Barely Legal, vol 4

Taboo, vol. 5

Dragon Ladies, vol. 2

Up n' Cummers, vol. 10

Dirty Debutantes, vol. 53

Re-embedding

Here I am in the bookstore. I find the book on urban density and copy down the information I need.

Here the abstract system of traffic literally solidifies into what MVRDV would call a datascape. Numbers take a material form and give rise to a new and artificial landscape above the existing cityscape that attempts to connect with a much larger and 
regional and supraregional scale. Not unusual in itself, perhaps, but the speed of developments and the contrast with the existing landscape has brought a spectacular quality to Guangzhou. One experiences this mainly below the new roads where-for the time being - the traditional city and traditional life continue to exist in some form as a kind of underworld. According to Anthony Giddens, the creation of abstract systems is the reason why traditional ways of life are being dis-embedded, deprived of their original social embedding. We are now in a phase in which these ways of life are re-embedded. This is literally visible in the riverbed at Guangzhou. Below, in the underworlds, traditional life carries on in the markets, temples and small streets, where goods for the market are still delivered by boat. Above are the new roads that carry their users far away in no time at all. ${ }^{\prime}$

It is this flexible vital principle that interests me.
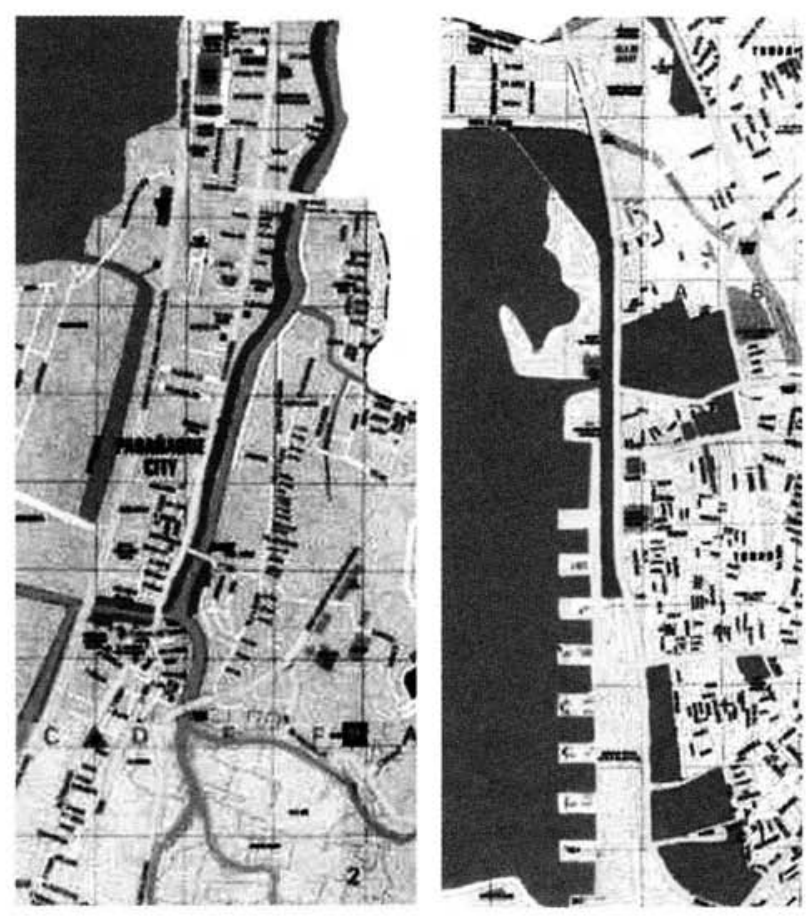

1 Bart Lootsma, "Counting In Guangzhou: Photographic Walk Through Guangzhou China," in FARMAX: Excursions on Density, Winy Maas, Jacob van Rijs, Richard Koek, eds. (Rotterdam: 010 Publishers, 1998), p. 475. 


\section{Shanty Town}

Shantytowns in Metro Manila are not on the outskirts of its constituent cities as they are in such places as Nairobi, Cape Town, or Durban, but are compressed within the center. They occupy the marginal and waste areas between the residential subdivisions and the land owned by factories and large landed families. These marginal areas are most characteristically along the channels of small streams and rivers and the tide-zones that buffer the city from Manila Bay. Built on these marginal areas, they are extremely compact. The following passage, which I discovered in a book by David C. Korten, at Power Books, a bookstore on the other side of Makati, describes them in an interesting organic manner.

Neon signs and sumptuous window displays deck the storefronts. But the alleys between the buildings look like human beehives, or termite colonies, with thousands of tiny cellular dwellings plastered precariously against the high brick walls. In each alleyway, a narrow central path, about two feet wide separates the shacks on either side. Made of bamboo slats and cardboard, most of the shacks consist of a single room, about six by eight feet square. Each shack lodges a whole family. On top of the first layer of shacks balances another layer of similar shacks, then another and another. In some alleys the shacks are stacked precariously five or six stories high. ${ }^{2}$

Yet the organic imagery suggests that these areas are true communities. While there are some minor divisions within them - usually along lines of province of origin - they nonetheless form closer communities than those whose homes, in the more affluent (gated) subdivisions nearby, feature protective fences that separate them from their neighbors. It was pointed out to me by Gary Devilles, my colleague at the Ateneo, that the marginalized residents of these shantytowns call themselves, ironically, mga taga-looban (insiders) and those who dwell in the subdivisions, "mga taga labas" (outsiders). They consider themselves the heart of the city.

${ }^{2}$ David C. Korten, The Post-Corporate World: Life After Capitalism (San Francisco, CA: Berrett-Koehler Publishers, Inc., 1999), p. 80. 


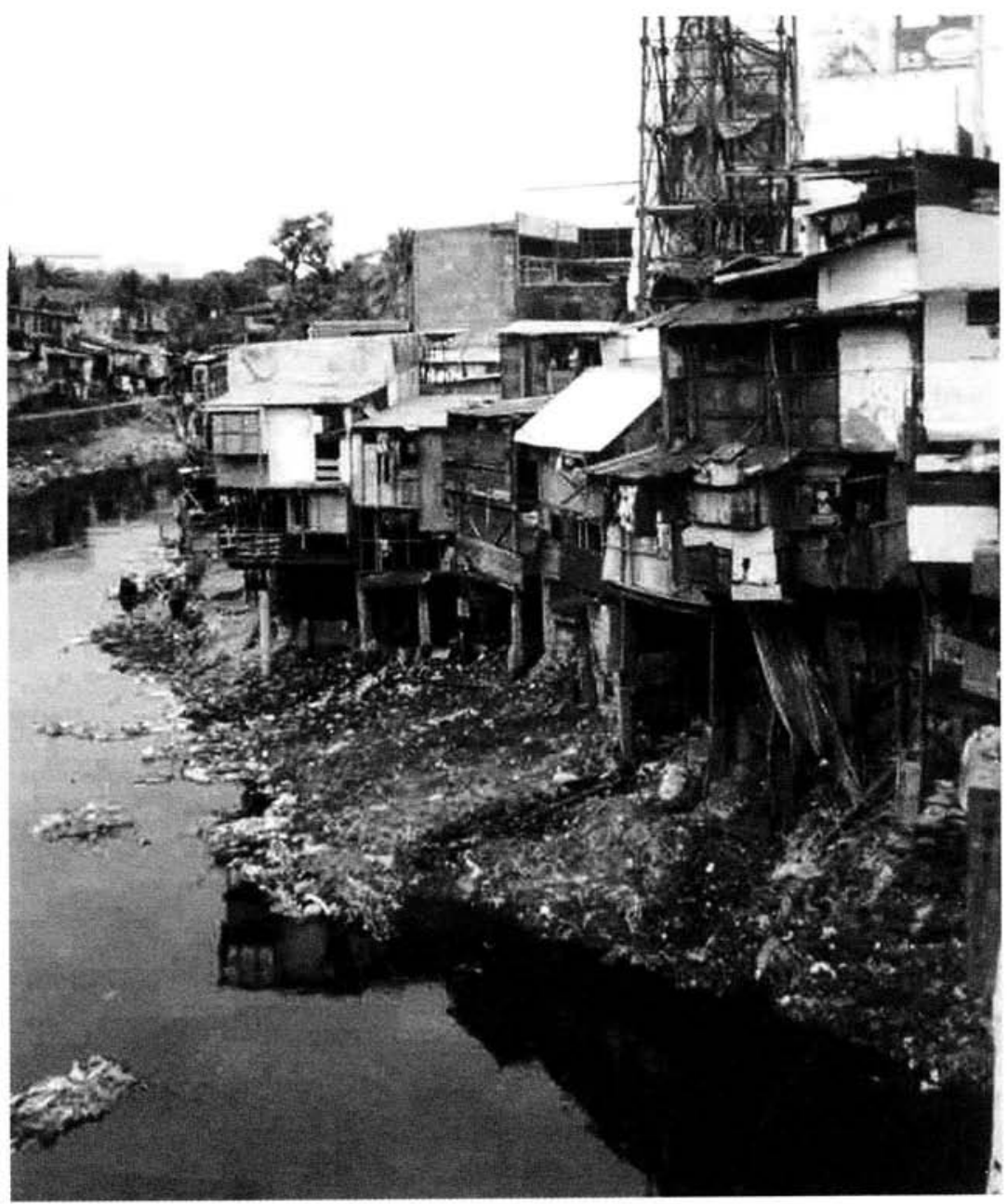

And so, here is a flow of forces that plays itself out along the seams of the city. It finds expression through organic architectures, streets with no name, ephemeral cityscapes periodically destroyed by fires or washed away by floods, but always re-embedding, reconstructing themselves.

And here, abstract systems come up against their natural limits. The promises, orderings and rationalities of global capitalism come up against their impotence, exhaustion, and emptiness. The consciousness of enlightenment modernism comes to face its shadow.

Abstract systems and datascapes would emphasis an uprooting, a loss of place and space, a destruction of time and nature. But the 


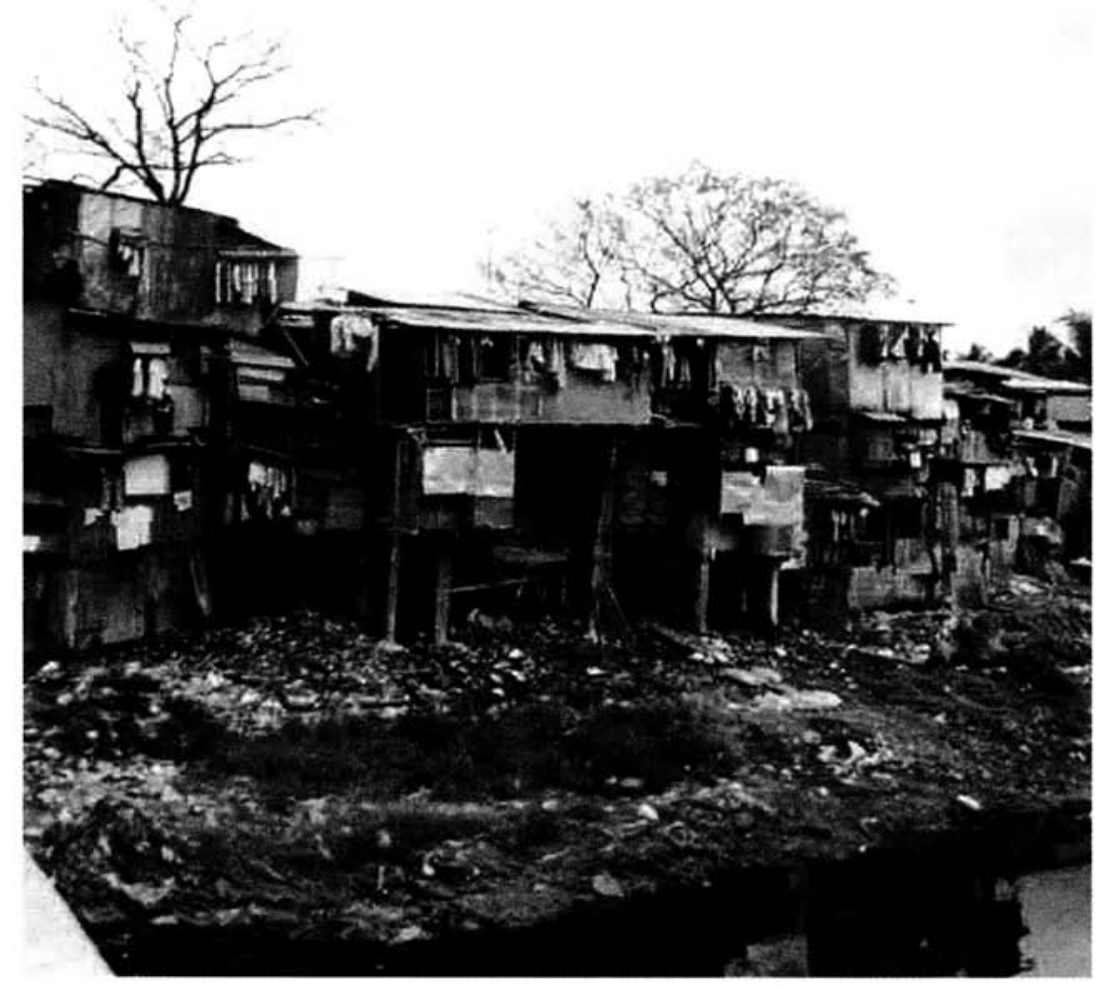

shantytown embeds itself along those areas most exposed to Nature (rivers, ocean fronts, flood-prone areas, typhoon-prone areas). It deploys waste material in its construction and emerges in a tangle of fascinating organic architecture. It follows an older logic of what LeviStrauss calls the bricoleur as opposed to the engineer. It falls back upon older forms of transportation such as boats, the rail-car. It fosters a real community, a down-to-earth logic and rationality.

We might say, then, that along the byways of Manila a new symbolism is emerging upon a fractured plane of interaction. On one end of it a rational organization of commercial desires and political discourse presents itself, and this is splashed on television, bannered upon billboards, peddled in shopping malls, universities, stock markets, and boardrooms. On the other end, a marginal, expressive flow of forces operating through hand-painted billboards, videoke rooms, symbolic Lenten crucifixions, plaster figures of saints, 
and magical amulets called anting-anting expressive of much older religious forms and superstitions.

We likewise find jeepneys equipped with horns that blare out the sound of wild laughter or of a rooster crowing, and painted on the outside with astrological signs, cartoon characters, the Santo Niño, naked women, pictures of babies and children, high school graduations, various expressive words in stylized writing, and even symbols taken completely out of context such as Nazi swastikas, confederate flags, corporation logos.

The shantytown presents itself as a disruptive marginal force bursting at the seams of development in terms as well of the geometric expansion of its population.

Instead of condemning the above-mentioned forms of expression, let us seek to understand their legitimacy.

\section{The fissure}

Hans Blumenburg in his book, Work on Myth, writes of the complicity of myth and enlightenment:

For with regard to the effort-which spans all of human history - to overcome anxiety relating to what is unknown or even still unnamed, myth and enlightenment are allies in a way that, while easy to understand, is reluctantly admitted ... [On one hand] every economy of ideas for which no rational foundation is given becomes suspect when it presents itself as the demand for submission to something for which no rational foundation can be given, and thus become the center of new anxieties. It can be rational not to be rational to the utmost extent... On the other hand, rationality is all too ready to engage in destruction when it fails to recognize the rationality of things for which no rational foundation is given, and believes it can afford to get carried away by the process of establishing rational foundations. Descartes thought that the best way to build cities rationally was to begin by razing the old cities. ${ }^{3}$

${ }^{3}$ Hans Blumenburg, Work on Myth, trans. by Robert M. Wallace (Cambridge, MA: The MIT Press, 1988), p. 163. 
The other of a rational system is not so clearly placed. It can take the form of an older rationality that presents a threat to the new foundation.

Michel de Certeau in his book, The Practice of Everyday Life, made the distinction between the "proper space" of the city and the "fact" of the city. Since de Certeau's book is unavailable-stolen from the library-lost somewhere in the labyrinth of the city-I shall quote instead from a book by James Donald.

[de Certeau] first describes the New York cityscape visible from the World Trade Center. This leads him to meditate on the temptation inherent in such a panorama... This representation is the fantasy that has motivated planners and reformers in their desire to make the city an object of knowledge and so a governable space. They dream of encompassing the diversity, randomness and dynamism of urban life in a rational blueprint, a neat collection of statistics, and a clear set of social norms.

Against this panoptic representation, de Certeau poses a representational urban space-what he calls the 'fact' of the city. The city that people inhabit is a labyrinthine reality which produces 'an anthropological, poetic and mythic experience of space.' In the recesses and margins of the city, people invest places with meaning, memory and desire... 'Beneath the discourses that ideologize the city' writes de Certeau, 'the ruses and combinations of powers that have no readable identity proliferate; without point where one can take hold of them, without rational transparency, they are impossible to administer.'4

For Donald, the value of de Certeau is that he gestures toward an often neglected poetic dimension to the city.

In the subjective life of the city dweller, there are no clear-cut boundaries between reality and imagination: Haunted places are the only ones people can live in. ${ }^{5}$

He connects this to Derrida's idea of the "spectre" and Zizek.

${ }^{4}$ James Donald, Imagining the Modern City (Minneapolis: University of Minnesota Press, 1999), p. 100.

${ }^{5}$ Ibid. 
To put it simply, reality is never directly 'itself', it presents itself only via its incomplete-failed symbolization, and spectral apparitions emerge in this very gap that forever separates reality from the real, and on account of which, reality has the character of a (symbolic) fiction: the spectre gives body to that which escapes (the symbolically structured) reality. ${ }^{6}$

\section{Symbolism fails... but for whom?}

The discourse that indulges in the play of symbols and heterogeneity, fails to account for the expressiveness of these marginal communities. Pious intentions notwithstanding, it is a dramatically western rationalist gesture to relegate them into the realm of "specter." Postmodernism in this respect would be the violence of modernism folding back upon itself. To an extent, this self-castigation is important for us academics. But we go too far when we want to swallow the world completely in our own circling indulgences.

The residents of shantytowns have perhaps still have not heard of the "death of God," the death of the transcendental signified, or the death of reality. If symbolism is something that fails, perhaps it fails only for the intellectual who is watching its operation from a detached position. In the channels of the shantytowns, these rationalities are still alive. They are always in the process of adapting to new conditions, of interfacing with the rationalities of the contemporary city. They carry the past with them as they deal with the present. Perhaps that is why the intellectual sees symbolism as failed.

We must now approach a peculiar aspect of symbolism that this intellectualization of symbolism cannot appreciate.

\section{Expressionism}

At the end of Lukács' essay on reification, he describes a conflict that occurs at the maximum density of late capitalism.

On one hand, there is an increasing undermining of the forms of reification-one might describe it as the cracking of the crust because of the inner emptiness-their growing inability to do

${ }^{6}$ Ibid. 
justice to the phenomena, even as isolated phenomena, even as the objects of reflection and calculation. On the other hand, we find the quantitative increase of the forms of reification, their empty extension to cover the whole surface of manifest phenomena. And the fact that these two aspects together are in conflict provides the key signature to the decline of bourgeois society. As the antagonism becomes more acute, two possibilities open up for the proletariat. It is given the opportunity to substitute its own positive contents for the emptied and bursting husks. But also it is exposed to the danger that, for a time at least, it might adapt itself ideologically to conform to these, the emptiest and most decadent forms of bourgeois culture.

What is this "positive content"? Lukács defines it according to his theory of objectivity and revolutionary consciousness. The danger would be the adoption of forms and symbols in a way in which his "objective" theory cannot anticipate. Lukács condemns expressionism because it succumbs to the danger of what might be considered an absent-minded embrace of empty capitalist symbols. Even artistic expressionism is condemned as decadent because it is merely the subjective expression of the fragmentation inherent in capitalist culture and so has no objective redemptive power.

Ernst Bloch answers Lukács' rejection of Expressionism.

What if Lukacs' reality-a coherent, infinitely mediated totality is not so objective after all?... What if objective reality is also discontinuity?... Since Lukács operates with a closed, objectivistic conception of reality, when he comes to examine Expressionism, he resolutely rejects any attempt on the part of artists to shatter any image of the world, even that of capitalism. Any art which strives to exploit the real fissures in surface interrelations and to discover the new in their crevices, appears in his eyes merely as a willful act of destruction. ${ }^{8}$

7 Georg Lukács, History and Class Consciousness, trans. by Rodney Livingstone (London: The Merlin Press Ltd., 1971), p. 208.

${ }^{8}$ Ernst Bloch, Aesthetics and Politics, Afterword by Fredric Jameson (London: Verso, 1990), p. 22. 
The debate here seems to be animated by a difference in the understanding of the position of the critic. Is the critic situated within the flow, looking at it straight on, or situated outside of it, standing back from it in order to capture its so-called objective form?

And even more interesting is how fissures in society reemerge as fissures in theories. Each theory has its own manner of addressing them, sometimes by dialectics as in Lukács, sometimes by the pious affirmation of difference and discontinuity as in post-structuralism and postmodernism. But what if within these fissures is a living force? What is taking place in these fissures and crevices?

\section{Walter Benjamin}

I have always been attracted to Walter Benjamin's writings, but I feel that he was caught in this same ambiguity. In one sense, he is the flaneur roaming the city streets and yet in another sense, he is detached, aloof. He never enters the interesting dwellings he describes from a distance, he never talks with the people he frames in his depictions. One never hears the voices of the city, the city is voiced only through the reflections of the detached academic. This gap, this fissure, is also framed within his theory in his attitude toward the expressions contained in city scenes and objects he encounters.

On one hand, the task of the critic is one of dream interpretation.

In the dialectical image, the pastness of a particular epoch is always also "things as they always have been." As such, though, at times it comes into view only at a very specific epoch: that is, the epoch in which humanity, rubbing its eyes, suddenly recognizes the dream image as such. It is at that point that the historian takes on the task of dream interpretation. ${ }^{9}$

This is a recognition that the past is only located in the present and somehow locked within our commodities and images, what Benjamin variously called: wreckage, runes, ruins, rebuses, and allegorical images.

9 Walter Benjamin, The Arcades Project, trans. by Howard Eiland and Kevin Mclaughlin (Cambridge, MA: Harvard University Press, 2002), N 4, 1. 
The images of our culture are the medium of our dreams, then the imaginative interpretation of those images break the spell and awaken us. Benjamin speaks of "dialectical images." The word, dialectic, is to be understood in a Kantian sense, or in connection with romantic irony. It is a tension between the "now" of familiarity (the dream states of modern culture), and the memories of the past that are stored up in the image (its origin, how it evolved through time).

Every Now is determined by those images that are synchronic with it: every Now is the Now of a specific recognizability. In it, truth is loaded to the bursting point with time. (This bursting point is nothing other than the death of the intention, which accordingly coincides with the birth of authentic historical time, the time of truth. ${ }^{10}$

So all of the objects and images of late capitalist culture are loaded with hidden histories. The job of the philosopher is to crack open the shell of these objects and images, and to liberate the truths, histories, and the sacred elements stored up inside of them. To break the spell of the familiarity of the now, Benjamin relies on various techniques: constellations, surrealistic montage, cabbalistic interpretation techniques and child-like play, but the goal is always the same, to recover what has been forgotten and buried in history to achieve a kind of messianic salvation from the destructive uncontrolled movement which calls itself "progress."

For the Critical Theorists, the philosophical implications of such thinkers as Jung were in dangerous proximity to the Fascism that was destroying Europe. Jung's archetypes were seen as historical forms, a return to the domination by myth and nature, which was being acted out by National Socialism's racial and imperialist mythologies. Theodor Adorno was worried about Benjamin's interest in collective wish images and dreams within history and so he encouraged Benjamin to distance himself from Jung. Benjamin at first agreed, but he never got around to writing this treatise, turning to his work on Baudelaire instead. But in The Arcades Project, Benjamin does warn about Jung's expressionism and its proximity to fascism. In one interesting passage he writes:

${ }^{10}$ Ibid., N 3, 1. 
The archaic form of primal history, which has been summoned up in every epoch and now once more by Jung, is that form which makes semblance in history still more delusive by mandating nature as its homeland."

In other words, the belief in timeless truth and primal history is a kind of double illusion. It is an inability to recognize the illusions of history as illusions. It is important that the dream states of history recognize themselves as such. Here he is close to the observation of Novalis: "we are closest to wakefulness when we dream that we are dreaming."

As a counterpoise to Jung, he quotes Victor Hugo.

Tradition, errant fable one collects, Intermittent as the wind in the leaves. ${ }^{12}$

Yet Benjamin in his writings never completely condemns the dreams and images of contemporary culture. They are not merely "errant fables." He often delights in them. At the same time that he affirms that the allegorical way of seeing does point to stations of decline, he calls for an overcoming of the idea of decline. At the same time that he affirms a messianic, negative-theological break from the movement of history, he draws us back into the diverse Ur-phenomena of history. This points to an ambiguity in Benjamin's philosophy that some consider a weak point. But this is an ambivalence that Benjamin shares with his mentor Baudelaire.

Foucault's observation concerning Baudelairean modernity could also apply to Benjamin.

For the attitude of modernity, the high value of the present is indissociable from a desperate eagerness to imagine it, to imagine it otherwise than it is, and to transform it not by destroying it but by grasping it in what it is. Baudelairean modernity is an exercise in which extreme attention to what is real is confronted with the practice of a liberty that simultaneously respects the reality and violates it. $^{13}$

"Ibid., N 11, 1.

${ }^{12}$ Ibid., N 8a, 1.

${ }^{13}$ Michel Foucault, "What is Enlightenment," in The Foucault Reader, ed. by Paul Rabinow (London: Penguin, 1984), pp. $40 \mathrm{f}$. 
The Marxist in Benjamin wants to destroy. The Romantic in him still wants to preserve.

Benjamin's separation of the allegorical from the symbolic, which represents a kind of failure of symbolism, leads to an important and interesting theoretical critique of history. But on the other hand, this approach aggressively distances the intellectual from the manner that symbols are still operating, are still alive, and still have something divine about them. This living flow of the symbol is often lost when we index them within a collection, a montage, or a theory. This is a kind of a blind spot in academic discourse. The chasm that runs through Benjamin's dialectical image is itself the life of the symbol, and so this fissure runs through the very center of Benjamin's philosophy. It also corresponds with Benjamin the flaneur who haunts the streets and byways of the city, yet never interacts with its inhabitants, and never really questions his own archival desires. Benjamin's approach to the fissure is fascinating and valuable, but it is still impotent since it never appreciates the life coursing through the veins of the city.

\section{The Recovery of Symbolism}

All of this suggests an unsolvable ambiguity lying at the heart of philosophical interpretation. The mythologist, Aby Warburg, struggling with his own mental fragmentation, writes:

All mankind is eternally and at all times schizophrenic. Ontogenetically, however, we may perhaps describe one type of response to memory images as prior and primitive, though it continues on the sidelines. At the later stage, the memory no longer arouses an immediate, purposeful reflex movement-be it one of a combative or a religious character-but the memory images are now consciously stored in pictures and signs. Between these two stages we find a treatment of the impression that may be described as the symbolic mode of thought. ${ }^{14}$

Giorgio Agamben points out the importance of Warburg's emphasis on the 'between' of stages.

14 Aby Warburg, quoted by Giorgio Agamben in Potentialities (Stanford, CA: Stanford University Press, 1999), p. 95. 
As the intermediary zone between consciousness and primitive identification, symbols did not appear to him as significant insofar (or only insofar) as they made possible the reconstruction of a personality or a vision of the world. For Warburg, the significance of images instead lay in the fact that, being strictly speaking neither conscious nor unconscious, they constituted the ideal terrain for a unitary approach to culture, one capable of overcoming the opposition between history, as the study of 'conscious expressions," and anthropology, as the study of "unconscious conditions."15

Could it be that Warburg realized in his own struggles with schizophrenia - the fissures and seams in his own thought - that the symbol is a living connection? One can easily see how one can lose this living aspect of the symbol by abstracting it into the play of symbols.

To characterize the real as a spectre is to be out of touch with the full force of the real, it is to underplay the irrational expressiveness of the symbol. Such thinkers develop a rational non-rationality to affirm difference, reducing everything to a play of symbols, while draining symbols of their seriousness, strife and life. On the margins of rational discourse, voices are often extremely logo-centric.

What takes place on the street cannot be dismissed as mere otherness, spectre, irrationality. The symbols and images of the street are a living connection. It is the very thing that hides within the seams and crevices of our intellectual theory and confounds them.

When I walk the streets of Manila, it is I who feel myself to be the ghost.

We cannot overcome binary oppositions, distorted histories, logocentrisms, phallocentrisms, eurocentrisms, religious fundamentalism. Whatever we create is imprinted in our environment and becomes real. There is a clash of rituals, histories, traditions, and symbols. And there is always a force of re-embedding of symbolic forces.

Isn't it a mistake for contemporary philosophy to be so concerned with messianism?

The residents of our shantytowns are icono-centric. This is their power and this is where the tide continues to rush back despite the attempts of global capitalism to keep it at bay. The life that animates

${ }^{15}$ Ibid., p. 99. 
tradition, continues to rush onward through its dreams, images and symbols.

So there also are seams in my head, perhaps, sometimes, more like wounds. And these seams when examined closely are also moving. This moving is a stream, a flow. And if I place myself within this flow, I find myself moving between books through city streets. If I think with any degree of coherence it is merely fleeting. Hopefully I come close to achieving it as I sit and write this paper. And in such instances, these seams in my thought can appear beautiful in their delineations. But how unfair to imprison them completely and impede their flow.

\section{SERVICE STATION SPIRIT HOUSE}

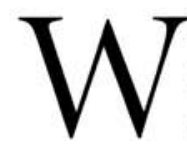

hat does progress look like from the outside, from a place not carried by its momentum? Or what does the struggle for redemption against progress look from the outside, from one not trapped within its momentum?

A practice, a drama, a dream, a recurring pattern, a demand, something that requires offerings of money?

There are global times, the times of the stock market, local times, geological time, eschatological times, and people pass through these times at will.

There is also the time of this essay ... projected out to you ... carrying within it its own expectations of a future ... addressing itself to known and supposed colleagues.

I am now - in Thailand - often faced with questions from colleagues and students concerning the Western concept of messianism that animates much of contemporary Western philosophy. This deep theological current upon which the hopes and projections of contemporary philosophy is based is something I have always assumed, but never really questioned. But the idea that it can appear somewhat foreign, has created an imbalance in my thinking from which I have yet to recover. So allow me to stumble along, hopefully forward, to some sort of articulation of the problem. 
The fear of globalization and contemporary capitalism involves the fear of the erosion of diversity. But we should ask, do people really assimilate to various forms, models, and temporalities? I am increasingly convinced that this fear is overstated. It is a mistake to follow the beliefs of those like Hegel and Fukuyama who would believe that everything is converging. People are essentially eclectic. They live quite well with contradictions. They can pass between times, realities, cultural practices, rituals and deities.

We can speak volumes about globalization and global economics, and I recognize that if we wish to be responsible philosophers, we need to be able to understand and critique flows of capital on this lofty scale.

But in this presentation I am interested in the margins of global flows, in what happens closer to earth.

\section{Externalities}

In Thailand and Cambodia it is very common to see what are called Spirit Houses. These are small houses supported on a post or posts, placed in a designated place on the property of someone's home or business. This is an old Animist tradition predating the arrival of Brahmanism and Buddhism in South East Asia. In Khmer it is called Neak Ta. In Thai it is sometimes called Phii Poota.

In building a house, various earth spirits ( $p$ hii) need to be placated. There is Phra Phum, who is a masculine owner of the land. Mae Thorani is the feminine spirit of the earth. Phra Nak is the chthonic snake spirit. Krun Bali is another chthonic spirit. And Nang Mai is the feminine spirit of the wood. These spirits are evoked and venerated when building a house. It is especially important to know how the Naga spirit is positioned before laying the first post. The Naga moves throughout the year, so the first post should be positioned at the belly of the Naga, at the axis of movement, ensuring stability and harmony with the earth.

There are two types of Spirit Houses. The shorter type, supported by four posts is designed for the veneration of ancestral spirits or Chao Phii. They often contain figurines of grandmother and grandfather spirits. The taller single post variety is called a San Phra Phum and is designed for the "lord of the land," an avatar of Vishnu or Narai. Terwiel in his book Monks and Magic describes the Phra Phum. 
Phra Phum derives his name from the word bhumi, which stands in Sanskrit and Pali for earth or soil. In Thailand he is often called Phra Phum chao thi; the epithet chao thi indicates that he is regarded as the owner of the land, its guardian spirit. The Venerable Phum is, however, not conceived of as a single entity that owns the earth: there are said to be several Phra Phum, each with his own realm ... Chayamongkhon, who guards houses, is the best-known Phum in Thailand; he is the inhabitant of the san Phra Phum, the shrine in the grounds of nearly all traditional houses in central Thailand. ${ }^{1}$

The story, which is derived from Indian and Thai myth, goes as follows. King Thotsarat and his sons ruled over the kingdom of Krungphali that covered the entire earth.

Later, the Lord of Krunphali did not live in righteousness and this caused much unhappiness among the people. The avatara of Phra Narai came down to earth in the form of a small Brahman who came to ask from the Lord of Krungphali a plot of land, only three steps wide, so that he could perform a ceremony. The Lord of Krungphali did not hesitate, gave his permission, and to solemnize this, poured udakadhara.

As soon as the water flowed, Phra Narai changed himself into Narai with four heads, and took his first step. With a single stride the whole earth was covered, and the Lord of Krungphali had to leave and live in a forest in the Himaphan. When he set out for this remote region he felt extremely sad and returned to beg for mercy. Phra Narai told him as solace: 'From now on, all humans ought to offer some food at the beginning of their ceremonies to Phra Phum, because he was the original owner of the earth. When this offer is performed, happiness will result. ${ }^{2}$

Here is a story which addresses the true owner of the land. King Thotsarat's kingdom covered the entire earth and he believed that he was the owner the earth. When he agreed to the celestial visitor's request

1 Terwiel, Monks and Magic: An Analysis of Religious Ceremonies in Central Thailand (Bangkok: White Lotus Press, 1994), p. 152.

${ }^{2}$ Ibid., p. 154. 
for a plot of land three steps wide, he thought that, as the owner of the land, he was being generous. Yet he is humbled to find that he is merely leasing the land from the visitor who is the true owner. After he repents, he and his sons are not punished but are given roles as guardians of the land. They become the nine Phra Phum angels (Thewada) who are venerated in the san Phra Phum shrines.

Notice that redemption is not escape or emancipation, not an openness to a utopian beyond, but a renewed and enlightened responsibility to what is already here.

It seems to me that almost every large business and petrol service station has a spirit house. The shrines at these businesses are much larger, of course, relative to the size of the business. The Phra Phum figure in these shrines is often replaced by a Brahma figure, a much higher and generic deity, in accordance to the larger size of the shrine. Offerings are made daily by the petrol station managers and attendants.

Garlands of flowers, food, joss sticks (incense sticks), a shot of Thai whiskey, ceramic figurines of elephants, archers and apsaras, occasionally even a toy robot or a Barbie doll, are placed before the spirit house standing in the corner of the service station grounds. The spirit house sits upon its foundation upon the earth, on what was at one time a rice field. The earth vibrates slightly when a large truck drives by on the street. The Naga slowly shifts in the earth. The trees sway overhead, above which, slowly, the clouds move across the sky, on their way towards Cambodia, Vietnam, and finally the South China Sea.

Inside the service station, the employees have punched their time clocks, the computer calculates the petrol being pumped out of its tanks, and calculates the money being paid, recording a desperate flow which motors the heavy movement of traffic on the streets. A nodal point of distribution and collection, connected to other nodal points across Bangkok, across South East Asia, across the globe.

And here, in one place, we have an overlapping of many places. The realm of Phra Phum as the true lord of the earth, and the business-place through which capital and petrol circulate according to the local traffic rhythms of Bangkok, the political rhythms of Thailand, and the global rhythms of corporate capitalism.

I wish to turn your focus only to the intersection itself. How do we characterize that space between service to global capitalism, and service to the land? Notice that one is based on what Adorno would call the 
exchange principle, while the other is a return of wealth to the land. It cannot be conceived in form of exchange. And it cannot be exhausted by the discourse of "the gift" which is always trapped within the plane of mere social relationships.

\section{Eclecticism}

In some Khmer Buddhist ceremonies, the laying out of the temple involves veneration to a deity of the earth (in this case Krun Bali).

The consecration must first be recognized by the Buddhist community, and often, it is considered that it must also be recognized by the divinities of space, soil, and in particular, by Krun Bali ... Krun Bali, himself, appears as the divinity of the ground or rather underground ... In her study about Krun Bali and the rites of the house, Mrs. Poree-Aspero, cites a tradition, according to which the Buddha permitted offerings to Krun Bali. She gives the translation of a manuscript passage that is related to it. According to this text, the Buddha recommends that "Krun Bali should be fed" under some circumstances, particularly when a Buddha image is built or when the simas of a temple are being laid. This is done in order to avoid the anger of Krun Bali, who when he gets irritated, "hits and scatters all the fruits of the god's actions." On the contrary, if we "feed Krun Bali," we receive "glory, felicity, dazzling happiness, and fame, along with as much of a fortune, or prosperity as we want." ${ }^{3}$

Notice also how Buddhist scripture and mythology is adapted to accommodate an earlier belief system. It accommodates, yet does not exhaust, it.

Out capitalist cosmology, represented by the service station, has not yet acceded respect to the true owner of the land. Granted, it prides itself on its toleration of a certain inculturation. It often uses it in its advertisements to convey its sensitivities to local cultures and the environment. Yet such gestures are hollow. Its logic is ultimately based on control and exploitation rather than on sacrifice and return.

3 Christophe Munier, Sacred Rocks and Buddhist Caves in Thailand (Bangkok: White Lotus Press, 1998), p. 80, quoting M. Giteau, Le bornage rituel des temples bouddiques au Cambodge, p. 4. 
The importance of eclecticism is that it maintains gaps, caesuras, and lapses of memory and logic that preserve the integrity of conflicting forces. These gaps have been appropriated by contemporary deconstructive approaches to philosophy, not as an act of preservation, but as a sign of the conceits of the system itself. Yet here we need to stress what is being preserved, and the passage between various types of logic, practices of space and time.

We can return here to Aby Warburg. While previously I had stressed the life of the symbol, here we can stress the symbol as an access to a hidden store of reflexes and wisdom.

All mankind is eternally and at all times schizophrenic. Ontogenetically, however, we may perhaps describe one type of response to memory images as prior and primitive, though it continues on the sidelines. At the later stage the memory no longer arouses an immediate, purposeful reflex movement - be it one of a combative or a religious character - but the memory images are now consciously stored in pictures and signs. Between these two stages we find a treatment of the impression that may be described as the symbolic mode of thought. ${ }^{4}$

This would suggest that spatial and temporal sensibilities are also stored in signs and rituals. These would constitute a preservation of a kind of sacred wisdom in the face of a profane disruption. Our more marginal religious practices whose conscious meaning seems to be lost, our superstitions and our commodifications of old spiritual beliefs, can be read as a kind of spiritual decline, but under other circumstances, they can constitute the seeds for a kind of renewal.

We can push the opposition of oil and spirit one step further.

At Erawan shrine, as at every Wat, when people make merit by making an offering on Wan Phra, they pour water over their hands and let it wash into the ground. This returns it to the underworld where it is stored.

There is a story which relates, that when the Buddha was being tempted by Mara, he asked the feminine spirit of the earth - Mae Thorani - to bear witness to his enlightenment. The Buddha touches the earth, Mae Thorani wrings out her hair, and at that moment, the waters

${ }^{4}$ Aby Warburg, by Giorgio Agamben in Potentialities: Collected Essays in Philosophy (Stanford, California: Stanford University Press, 1999), p. 95. 


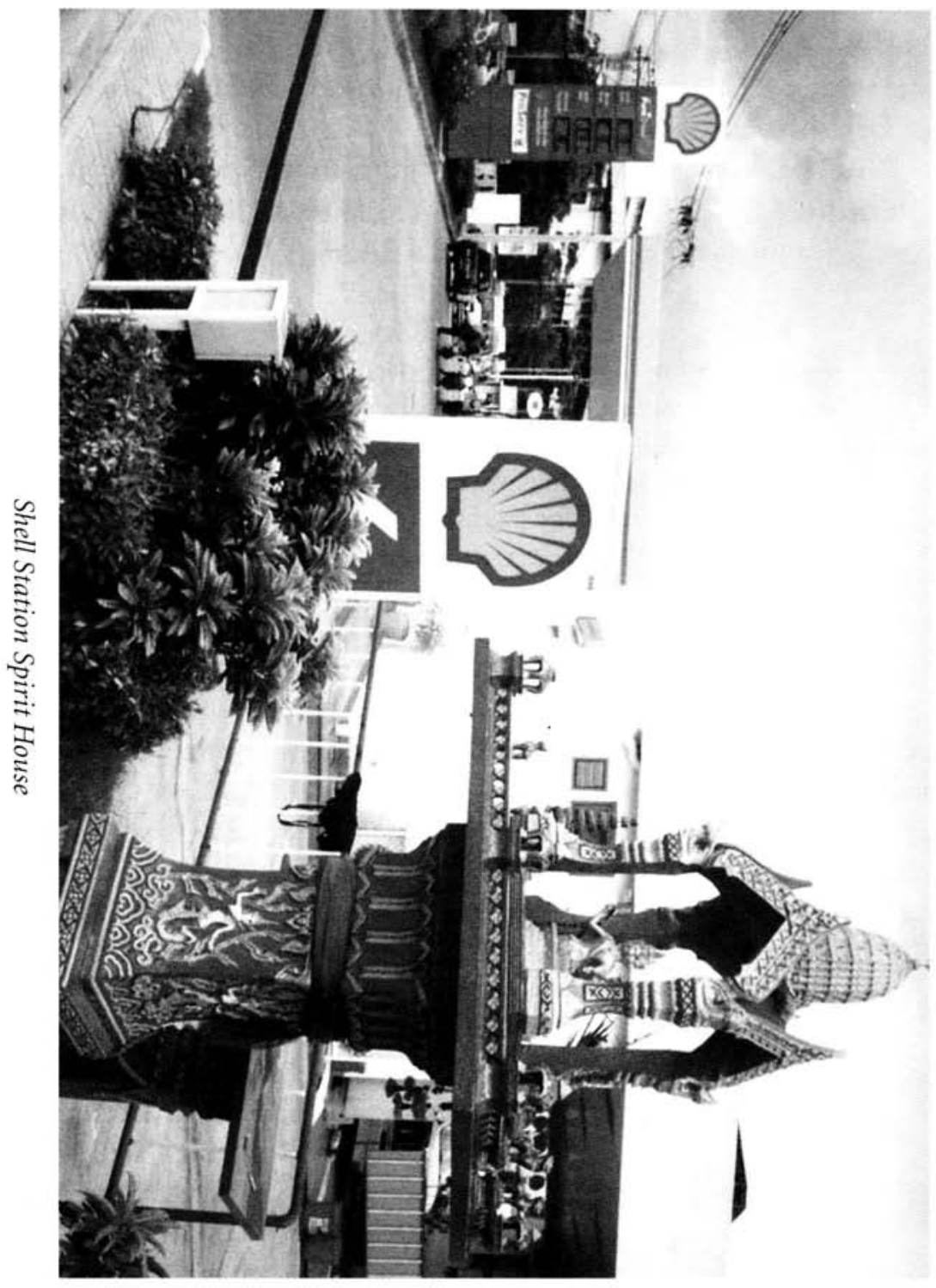




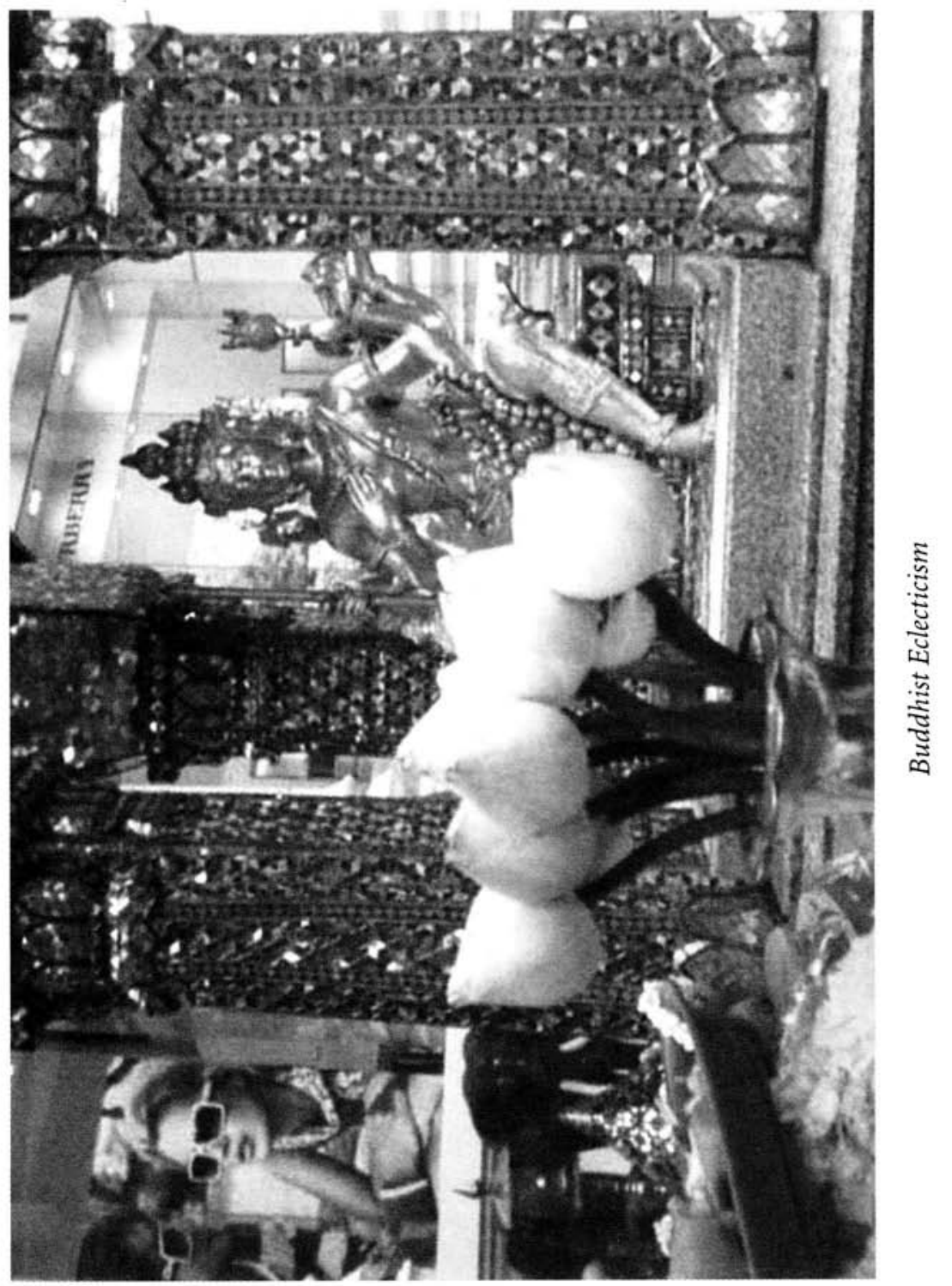


of the earth rise up to wash away Mara and his associates. The waters which rise up comprise the accumulated reservoir of merit.

We can contrast the drawing of oil from the earth, the defilement, exhaustion of nature, with an attitude which gives-back to the earth. A vertical dimension of return flow.

\section{Secular Messianism}

And while we depart from the trajectory of historical thinking which affirms convergence, likewise we depart from the thinking which resists convergence.

Adorno, in his essay on Hölderlin, titled "Parataxis," develops a soteriology which is based on liberation of humanity from both myth (the domination by nature) and the domination of nature by humanity through rationality and the exchange principle.

For demythologization itself is nothing other that the selfreflection of the solar Logos, a reflection that helps oppressed nature to return, whereas in myth nature was one with the oppressing element. Only what gives myth its due can provide liberation from myth. The healing of what the romanticmythologizing thesis conceives reflection to be guilty of is to occur, according to the Hölderlinian antithesis, through reflection in the strict sense, through the assimilation of what has been oppressed into consciousness through remembrance. ${ }^{5}$

Our liberation from myth also involves the liberation from the idea that there is a pure state of nature which was lost. This frees us from the anxiety of origins and leaves us in a state of peace.

But genius is spirit in that it defines itself as nature through self-reflection; the reconciliatory moment in spirit, which does not exhaust itself in the domination of nature but remains and exhales after the spell of the domination of nature has been shaken off, a spell which turns that which dominates to stone as well. Genius would be consciousness of the non-identical object. To use one of Hölderlin's favorite terms, the world of genius is "das Offene."

${ }^{5}$ Theodor Adorno, "Parataxis: On Hölderlin's Late Poetry," in Notes to Literature, Vol. 2 (New York: Columbia University Press, 1992), p. 141.

${ }^{6}$ Ibid., p. 146. 
Genius would be that state of reconciliation with nature, liberated both from myth-religion and enlightenment rationality.

This model of redemption is quite common today. We can see it when Derrida speaks of a "messianism without religion."

[W] hat remains irreducible to any deconstruction, what remains as undeconstructable as the possibility itself of deconstruction is, perhaps, a certain experience of the emancipatory promise; it is perhaps even the formality of a structural messianism, a messianism without religion, even a messianic without messianism, an idea of justice - which we distinguish from law or right and even from human rights - and an idea of democracy - which we distinguish from its current concept and from its determined predicates today. ${ }^{7}$

Here the idea of redemption is preserved while there is an escape from religious idolatry.

This retaining of religious soteriology, while overcoming religious symbolism is explained well by Timothy Bewes. Its purpose is a response to the anxiety of late capitalism and reification. Bewes, like Adorno, suggests that religion and reification are distortions which can be overcome only when they are completed.

The disappearance of religion, to restate a theme of this book, is only possible with the disappearance of reification. The key to removing both events from the merely speculative dimension is the recognition of their reversibility. The disappearance of religion is identical to the realization of its truth, to the manifestation of its objects of devotion, to the erasure of the semiotic disjunction between faith and parousia, an event which religion itself could not survive. Likewise, the disappearance of reification would be identical to its totalization. ${ }^{8}$

The key to redemption is removing all illusion which maintains a distance from nature. A symbol, while pointing to a kind of truth, also leads to idolatry and logocentrism. So redemption is a movement beyond the particulars of symbolism (which in many interpretations has lost its power) and a movement towards that pure space of truth beyond the symbol.

${ }^{7}$ Jacques Derrida, trans. by Peggy Kamuf, Spectres of Marx: The State of Debt, The Work of Mourning, and the New International (New York: Routledge, 1994), p. 59.

${ }^{8}$ Timothy Bewes, Reification: or the Anxiety of Late Capitalism (London: Verso 2002), p. 262. 
Is not the discourse of alterity much like the scientific movement beyond anthropomorphism? In both cases there is fear of projecting one's biases into what one is trying to understand. Both involve a myth of objectivity. And in both cases, the result is so rarified as to be sterile (is there anything as empty as the idea of a "general economy" or "field of difference"?) We can see the ultimate emptiness of this trajectory in the writings of Ernesto Laclau.

As far as the rationalistic dimension is concerned, we should take into account that the secularist turn of modernity involved both the assertion that the meaning of history is not to be found outside history itself, that there is no supernatural power operating as the ultimate source of everything that exists, and the very different assertion that this purely worldly succession of events is an entirely rational process that human beings can intellectually master. Thus reason reoccupies the terrain that Christianity had attributed to God. But the eclipse of the ground deprives reason of its all-embracing abilities and only the first assertion (or rather commitment), the intraworldly character of all explanation, remains. Reason is necessary, but it is also impossible... but through this failure we gain something perhaps more precious than the certainty that we are losing: a freedom vis-à-vis the different forms of identification, which are impotent to imprison us within the network of an unappealable logic. ${ }^{9}$

Ultimately, Laclau writes, human beings can recognize themselves as "true creators" and "as all social agents have to recognize their concrete finitude, nobody can aspire to be the true consciousness of the world." Here, we have returned to Adorno's generalized concept of genius. This rehabilitation of emancipation is also based on a kind of reduction of all rationalities and practices to a unified but unstable surface. It is the surface of a fragmented secular rationality drained of magic and mystery.

This same mechanism is supposed to save us from the reifications of late capitalism. To move us beyond our dangerous deceptions and lead us to a reconciliation with nature - towards a kind of immanence. We see this clearly in the work of Hardt and Negri. They follow the inspiration of Nietzschian philosophers like Deleuze and Guattari, in their celebration of this same field of immanence.

\footnotetext{
${ }^{9}$ Ernesto Laclau, Emancipation(s) (London: Verso, 1996), p. 16.
} 
A new vitality, almost like the barbaric forces that buried Rome, reanimates the field of immanence that the death of the European God left us as our horizon. Every theory of the decline of the idea of European Empire is in some way a symptom of the new vital force of the masses, or as we prefer, of the desire of the multitude. ${ }^{10}$

Yet this as well involves a movement which condemns the transcendent.

What in the midst of the crisis in the 1920s appeared as transcendence against history, redemption against corruption, and messianism against nihilism now was constructed as an ontologically definite position outside and against, and thus beyond every possible residue of the dialectic. This was a new materialism which negated every transcendent element and constituted a radical reorientation of spirit. ${ }^{11}$

The fields which we see outside of the so-called crises of the West, are fields not only of rhizomal-grass, but of trees as well. We see this in the major world religions and the manner in which their roots extend deeply into the earth. We see this dramatically in the animism that animates the practices of Christianity in the Philippines, Buddhism in Thailand and Cambodia, and Islam throughout Malaysia and Indonesia. These practices do not seem to be connected to the same crisis of thought, of progress, and of the dialectic, that one finds in the West. They do not possess the same brittleness that would lead to their easy collapse into a single intellectual plane of immanence.

These contemporary writers - while contributing important insights into our contemporary situation - also repeat the mistakes of the homogeneous systems they are resisting.

I should make clsar that I am not defending the fundamentalisms (Christian, Muslim, Jewish, Hindu and Buddhist) that are creating so many problems today. As Karen Armstrong points out, they abandon mythos and embrace logos. They borrow the tools of the secularism that they consider to be their enemy. These fundamentalist movements, while having some authentic religious content, are however more the manipulation of political power. As a result, they have developed into a sterile system for the mere circulation of wealth, privilege and territory.

${ }^{10}$ Michael Hardt and Antonio Negri, Empire (Cambridge, Massachusetts: Harvard University Press, 2001), p. 377.

"Ibid, p. 378. 
They, too, repeat the mistakes of the secularisms they are resisting. They do not connect to any spiritual power.

Reifications as we see in Warburg, can store up and preserve a wisdom. Benjamin realized the same thing. Yet Benjamin also believed that redemption can only be achieved by breaking open all the vessels and emptying them out into the yawning mouth of history.

It is difficult to deny the legitimacy of such a desire. Yet if we look towards the future, what is more likely needed is a guide for our eclectic beliefs. If we inherit such ruins as modernity, postmodernity, linear time, circular time, religious and secular rituals, capitalist and socialist rituals, ancient wisdom and scientific rationalities, fortune telling and satellite imagery, the trick is not placing them in constellations to merely overcome them, but to weave them together to create some balance and grounding for whatever type of political arrangements we find ourselves.

We need to respect a power which intercedes from above and below — like the Phra Phum or the Naga — not a collapse of all transcendents to pure immanence, not a redemption deferred into some messianic future, but something which speaks from both the past and the present.

Post ...

What does progress look like from the outside, from a place not carried by its momentum? Or what does the struggle for redemption against progress look from the outside, from one not trapped within its momentum?

A practice, a drama, a dream, a recurring pattern, a demand, something that requires offerings of money?

The appreciation of a loose syncretism, an eclectic co-habitation of practices, rituals, logics within the same experience, points to the necessity of a multitude of redemptive models, and sometimes merely the lack of them - the affirmation of the moment. The moment behind the service station when the joss sticks are lit and placed on the shrine. When the flows of traffic, petrol, and money, momentarily stop.

The future is not all that unforeseeable, counter to the messianic claim. Breakdowns of unsustainable practices of Capitalism will lead to radical localizations, fragmentations, and the need for the return 
of strong ritual practices. But it will also involve the need to utilize the remnants and ruins of the "progressive past" on the other. What people will have to work with in the future are their eclectic beliefs. Their traditional beliefs, on the one hand and, on the other, what they have inherited from the exotic traditions of modernity and technology.

And we here are engaged in an academic ritual. We who engage in our rituals of reading, writing, research. These of course can be cynically reduced to mere commodity fetishism, and yet, there is an important gesture involved here. Reaching across a certain distance. To the past, toward a future. Perhaps we, too, are schizophrenics like Warburg.

But perhaps it is our ambivalences and ambiguities, our lapses of logic, which preserve something important. $\oslash$ 